\title{
Seronegative glandular fever
}

\author{
H. G. PENMAN
}

From Queen Alexandra Hospital, Cosham (Portsmouth and I.o.W. Area Pathological Service)

SYNOPSIS Seven sporadic cases of 'seronegative glandular fever' have been examined in detail; five of the patients were adults aged more than 30, two were children. None showed evidence of 'incom- $\stackrel{\omega}{\sigma}$ plete' or heat-labile sheep cell agglutinins, but in three very weak, though otherwise typical, glandular용 fever agglutinins were detected. Three of the other four showed evidence of certain infections, buti these infections probably accounted for no more than a part of each illness.

It is suggested that some, and possibly most, sporadic cases of seronegative glandular fever are ir of the same disease as seropositive cases, the patients' ages influencing the serological response. 음 Certain conditions of known aetiology may, however, be clinically and haematologically indistin- guishable from seronegative glandular fever.

The nature of cases showing clinical and haematological signs of glandular fever, but remaining negative in the heterophile agglutination test, has been debated since the introduction of this test. Shubert, Collee, and Smith (1954) regarded such cases as being of a different disease from seropositive glandular fever, but nevertheless closely allied to it. Hobson, Lawson, and Wigfield (1958) also regarded the two conditions as being different diseases, but quoted Niederman (1956) who regarded them as being the same, as did Evans (1960). The issue is confused further because several conditions of known aetiology can produce clinical and haematological appearances indistinguishable from those found in glandular fever. Amongst these conditions are acquired toxoplasmosis (Beverley and Beattie, 1958; Siim, 1960); brucellosis (Conway, 1949); listeriosis (Girard and Murray, 1951); rickettsial infection (Misao, Kobayashi, and Shirakawa, 1957); cytomegalovirus infection (Klemola and Kääriäinen, 1965); reactions to certain drugs, including para-amino-salicylic acid (Lichtenstein and Cannemeyer, 1953), phenylbutazone (Lawrence, 1960), and sulphone drugs (Lowe and Smith, 1949); and a febrile state occasionally occurring three to five weeks after surgery with blood transfusion (Ross, 1964; Smith, 1964). The present paper describes detailed investigations carried out in seven sporadic cases of glandular fever that were seronegative on routine testing.

\section{MATERIALS AND METHODS}

The seven cases were the only examples of seronegative Received for publication 17 March 1967. disease in a series of 47 cases of glandular fever (Penman, $\vec{\varphi}$ 1966). In all seven a history was taken and a clinical examination made. Venous blood was obtained for routine haematological tests, A B O blood grouping, the heterophile agglutination test and modifications of it, the Wassermann reaction (in adults), anti-streptolysin $\mathbf{O} \overline{\bar{O}}$ estimation, tests for toxoplasmosis, the brucella agglutina-ڤొ tion test, and for virus serology. In six cases blood cultures $\stackrel{\curvearrowright}{\Phi}$ were carried out; throat swabs were taken for culture in all $\vec{F}$ seven. Virus isolation was attempted from faeces in allo윽 cases, and from throat swabs when the illness had lasted less than a week. All the patients were re-examined after intervals ranging from 13 to 26 days and certain of the tests were repeated. Three patients were seen on more than two occasions. The standard laboratory methods used? have been described elsewhere (Penman, 1966), and only certain details of the special tests will be given here.

Dye tests (Sabin-Feldman) and, in some cases, comple- $\varrho$ ment-fixation tests for toxoplasmosis were undertaken by Dr. D. G. Fleck at the Public Health Laboratory, Swansea, 윽 by the methods of Fleck and Payne (1963). Complementfixation tests for antibodies against certain viruses (see음 Table III) were carried out by Dr. L. A. Hatch at the Public Health Laboratory, Portsmouth, as were the virus isola- $\sigma$ tions. The serological methods were those of Fraser and $N$ Hatch (1959) except that fixation was allowed to proceed overnight at $4{ }^{\circ} \mathrm{C}$. before the sensitized sheep-cell suspens- $\omega$ ion was added. Isolations were attempted in secondary monkey (either rhesus or cynomologus) kidney, primaryo human amnion, and HeLa cell tissue cultures.

For the heterophile agglutination test, sera, inactivated@? at $55^{\circ} \mathrm{C}$. to $56^{\circ} \mathrm{C}$. for 30 minutes, were absorbed overnight in the refrigerator with four times their volume of approxi- $-\bar{O}$ mately $2 \%$ guinea-pig kidney suspension. One drop volumes of the supernatants were then mixed with one $\frac{\rho}{\Phi}$ drop volumes of a $1 \%$ to $2 \%$ sheep-cell suspension (thee sheep cells, washed and prepared before each test, being 
not less than one day and not more than five days old) in small tubes, which were then incubated at $37^{\circ} \mathrm{C}$. for one hour, followed by an hour at room temperature. They were examined macroscopically after gentle tapping. None of the sera from the seven patients produced agglutination in this test. Anti-sheep cell activity was also sought using five special methods. Sera which had been stored at $-18^{\circ} \mathrm{C}$. were tested; the sheep cell agglutinin keeps well on storage (Bernstein, 1940; Davidsohn and Lee, 1964).

1 TEST FOR AGGLUTININS ACTIVE IN AN ALBUMIN MEDIUM The test was set up as already described, but incubation was at $37^{\circ} \mathrm{C}$. for two hours; at one and a half hours the fluid was removed from the sedimented cells and replaced by a drop of $20 \%$ bovine albumin. The results were read macroscopically.

2 TEST FOR 'ANTIBODIES' BY THE COOMBS TECHNIQUE The details of the method were as described by Dunsford and Bowley (1955), except that sheep cells and inactivated sera were being used.

3 TEST FOR 'BLOCKING ANTIBODIES' Procedure was as in the heterophile agglutination test, but after the incubation the supernatant was removed and the cells washed once in saline. They were then resuspended in a drop of saline and a drop of 'challenge serum' was added. This was the supernatant, after guinea-pig absorption, of a known weakly positive serum. It was also added to untreated sheep cells as a control. The tubes were shaken and incubated again as before, after which the strength of agglutination in the control was compared macroscopically with that of the test.

4 TEST FOR AGGLUTININS DESTROYED BY HEAT INACTIVATION Uninactivated, unabsorbed serum was diluted with four parts of saline and tested for sheep cell agglutinins as in the heterophile agglutination test, except that an approximately $1 \%$ sheep cell suspension was used. If haemolysis occurred, the serum was retested after the addition of a little E.D.T.A. Any agglutinins detected were subsequently titrated, and compared with the titre in the inactivated serum.

5 TEST FOR VERY WEAK AGGLUTININS Inactivated serum was absorbed with five times its volume of $20 \%$ guinea-pig kidney suspension (overnight in refrigerator). The supernatant was then serially diluted (doubling dilutions in physiological saline) in one drop volumes, to each of which a drop of an accurate $2 \%$ suspension of sheep cells was added. After an hour at $37^{\circ} \mathrm{C}$. and an hour at room temperature, agglutination was looked for microscopically. In those cases in which agglutination occurred, the test was repeated together with titrations of the unabsorbed serum and of the serum absorbed with $20 \%$ ox cell suspension.

\section{RESULTS}

The illnesses in these seven cases resembled that commonly observed in seropositive glandular fever, though in the five adults (all over 30 years of age) pharyngitis was not severe. The two children were both aged less than 10 years. None of the patients had recently undergone surgery or been transfused, and none was known to be taking drugs for other diseases. Their blood films showed no features distinguishing them from patients with seropositive disease. The interval between onset of symptoms and the last heterophile test in each case is shown in Table II. Six patients belonged to blood group $\mathrm{O}$, one to group $\mathrm{A}$.

All the patients' sera gave negative results in the first four special tests for anti-sheep-cell activity (except the third and fourth sera from case 1 which were not submitted to tests 1 and 2, and the third serum from case 1 and the second from case 3 which were not submitted to test 3 ). In test 5 , however, five sera showed agglutinins persisting after guinea-pig kidney absorption. These sera, subjected to the full absorption procedure, gave the titres shown in Table I.

\section{TABLE I}

SHEEP CELL AGGLUTININ TITRES ACCORDING TO TEST 5

\begin{tabular}{lllll}
$\begin{array}{l}\text { Case } \\
\text { No. }\end{array}$ & Serum & Unabsorbed & $\begin{array}{l}\text { Guinea-pig } \\
\text { Kidney } \\
\text { Absorbed }\end{array}$ & $\begin{array}{l}\text { Ox Cell } \\
\text { Absorbed }\end{array}$ \\
\hline 1 & 1st & 40 & 10 & $<10$ \\
2 & 2nd & 20 & 10 & $<10$ \\
6 & 1st & 40 & 20 & $<10$ \\
7 & 2nd & Not tested further & 20
\end{tabular}

In cases 1,2 , and 6 there were thus typical, but very weak, glandular fever agglutinins. The result in case 7, confirmed on repeating the test, was atypical and indicated either an agglutinin distinct from that found in glandular fever or a combination of the latter with an agglutinin not absorbed by ox cells. None of $\mathbf{5 0}$ control sera (taken from 30 patients thought not to have glandular fever) showed typical glandular fever agglutinins by this technique.

Tables II and III show the results of various other investigations carried out in the seven cases. There is no good evidence of specific infecting agents as causes of the illnesses in cases 1, 2, 3, and 6. In cases 1 and 6 the serological results indicate recent infections with $\beta$ haemolytic streptococci and influenza $C$ virus respectively, but the falling titres and short histories show that these infections antedated the onset of glandular fever. Cases 4 and 5 show raised, but not rising, titres of antibody against Toxoplasma gondii and mumps virus respectively. E.C.H.O. virus type 9 was isolated from the faeces in case 7; this patient's illness consisted first of posterior neck pain and vague malaise, with lymphadenopathy, splenomegaly, and facial nerve palsy later. In none of the seven cases was there serological evidence of active brucellosis, and the Wassermann reaction was negative in the five adults. 
TABLE II

RESULTS OF INVESTIGATIONS IN SEVEN CASES OF SERONEGATIVE GLANDULAR FEVER

\begin{tabular}{|c|c|c|c|c|c|c|c|}
\hline \multirow{2}{*}{$\begin{array}{l}\text { Case } \\
\text { No. }\end{array}$} & \multirow{2}{*}{$\begin{array}{l}\text { Age, } \\
\text { Sex }\end{array}$} & \multicolumn{2}{|c|}{ Highest W.B.C. (per c.mm.) } & \multirow{2}{*}{$\begin{array}{l}\text { Timing of } \\
\text { Heterophile Tests } \\
\text { (days after onset) }\end{array}$} & \multirow{2}{*}{$\begin{array}{l}\text { Horse cell } \\
\text { Agglutinins } \\
\text { (stored sera) }\end{array}$} & \multirow{2}{*}{$\begin{array}{l}\text { Throat } S w a b^{3,4} \\
\text { (bacteria) }\end{array}$} & \multirow[t]{2}{*}{ Blood Culture } \\
\hline & & Total & Mononuclears ${ }^{1}$ & & & & \\
\hline 1 & $48, M$ & 15,600 & 13,260 & $\begin{array}{r}7 \\
14 \\
21 \\
70\end{array}$ & $\begin{array}{l}-\mathrm{ve} \\
-\mathrm{ve}\end{array}$ & $\begin{array}{l}\text {-ve(aer) } \\
\text {-ve(aer) }\end{array}$ & $\begin{array}{l}\text { Diphtheroids } 5 \\
\text { at } 4 \text { days }\end{array}$ \\
\hline 3 & $5, M$ & 28,000 & 16,800 & $\begin{array}{r}6 \\
20\end{array}$ & $-\mathrm{ve}$ & $\begin{array}{l}\text { Staphs. } \\
\text {-ve(aer) }\end{array}$ & - \\
\hline 4 & $40, F$ & 10,100 & 7,171 & $\begin{array}{l}13 \\
28 \\
55\end{array}$ & $\begin{array}{l}\text {-ve } \\
\text {-ve }\end{array}$ & -ve(aer/an) & Sterile \\
\hline 5 & $59, \mathrm{~F}$ & 13,600 & 9,520 & $\begin{array}{l}18 \\
31\end{array}$ & $\begin{array}{l}\text {-ve } \\
\text {-ve }\end{array}$ & $\begin{array}{l}\text { Streps. } \\
\text { Streps. }\end{array}$ & Sterile \\
\hline 6 & $5, M$ & 21,500 & 15,125 & $\begin{array}{r}2 \\
28\end{array}$ & $-v e$ & Staphs. & Sterile \\
\hline 7 & $41, \mathrm{M}$ & 15,600 & 12,480 & $\begin{array}{r}2 \\
16\end{array}$ & & $\left.\begin{array}{l}\text { Staphs. } \\
\text { Haemoph. } \\
\text { Staphs. }\end{array}\right\}$ & Sterile \\
\hline
\end{tabular}

${ }^{1}$ Mononuclears $=$ lymphocytes, monocytes, and atypical cells. At least $25 \%$ of the mononuclears in each case were abnormal.

${ }^{2}$ Denco - IM test, Denver Laboratories, Ltd., London, N.W.9. See Hoff and Bauer, (1965)

Aer. = aerobic; an. = anaerobic

Staphs. = coagulase-positive Staph. aureus

Streps. = bacitracin-sensitive $\beta$ haemolytic streptococci

Haemoph. = haemolytic haemophilus or parahaemophilus organisms

${ }^{5}$ Long, clubbed, Gram-positive organisms; non-haemolytic; non-motile in broth culture at $23^{\circ} \mathrm{C}$

TABLE III

RESULTS OF INVESTIGATIONS IN SEVEN CASES OF SERONEGATIVE GLANDULAR FEVER

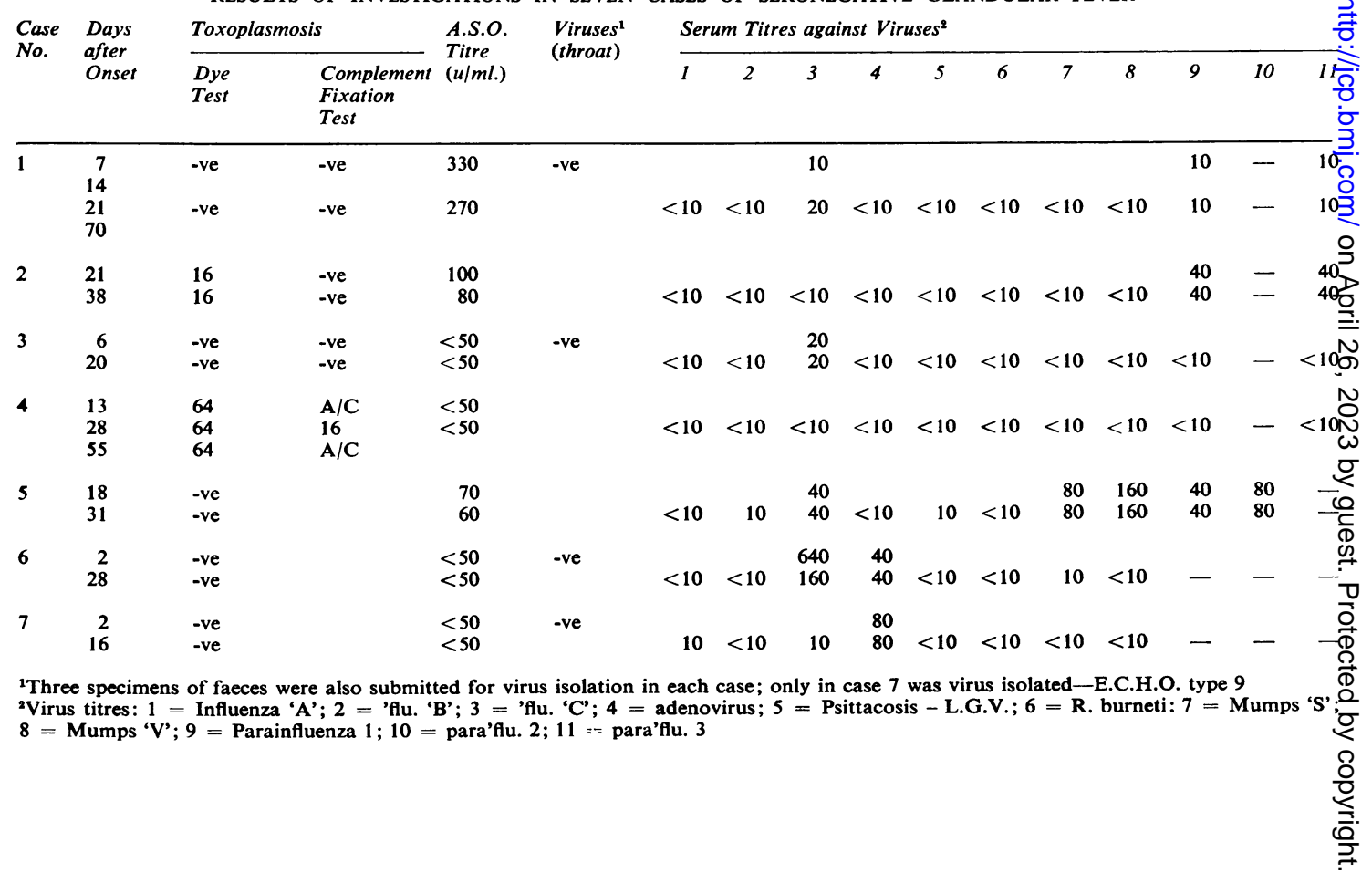


Three of the seven patients thus showed weak, but otherwise typical, glandular fever agglutinins, and no evidence of any specific infection as a cause of the illness. Of the remaining four, three showed evidence of specific infections which might have played some part in the illnesses (see discussion).

\section{DISCUSSION}

There is much disagreement as to when glandular fever can properly be called seronegative. Many authors, e.g., Hobson et al. (1958) and several others cited by Penman (1966), regard a heterophile agglutination result as negative if the titre after guinea-pig kidney absorption fails to reach a certain level. It is not clear why typical, but low titre, agglutinins are ignored. No other condition has been shown to cause the appearance of sheep cell agglutinins with the characteristics of those found in glandular fever. Accordingly, I have followed authors who regard as seronegative only those cases in which no typical agglutinin at all is detected (Leibowitz, 1953; Davidsohn and Lee, 1962).

Glandular fever may be mistakenly called seronegative if the development of the agglutinins is delayed till after the time of the last test. A review of the relevant literature (Penman, 1966), however, showed that probably at least $90 \%$, and possibly well over $90 \%$, of the cases which ultimately become seropositive will have become so by the end of the third week of illness. Nevertheless, occasional cases may not become seropositive until the third month. Thus some of the present cases, particularly cases 3 and 7 , might have been demonstrably seropositive if later tests had been done.

The failure of the seven patients to become seropositive was not due to their 'antibody' being 'incomplete' or heat-labile. Mason (1951) also failed (in 14 seronegative cases) to demonstrate agglutinins by the albumin technique. Likewise, Belfrage (1962) and Lee, Takahashi, and Davidsohn (1963), using the Coombs test, found little evidence of incomplete agglutinins in glandular fever. Eyquem, Fine, Mailloux, and Podliachouk (1955), however, referred to the demonstration of such antibodies by other authors, though it seems that these authors had modified the Coombs test by making their test serum dilutions in human serum. Levine and Gilmore (1945), in a single case, did demonstrate a 'blocking antibody' effect.

The combined use of a weak cell suspension and microscopic reading of results has been little used in the heterophile agglutination test. Shubert et al. (1954) used a $0.2 \%$ cell suspension in investigating three seronegative cases; they thereby achieved higher unabsorbed titres, but the agglutinins were com- pletely absorbed by guinea-pig kidney. Heat inactivation is generally assumed to have no destructive effect on the agglutinins. Lee et al. (1963) found only a $50 \%$ drop in titre if sera heated for half an hour at $56^{\circ} \mathrm{C}$. were heated for a further quarter of an hour at $60^{\circ} \mathrm{C}$.

The serological evidence of toxoplasmosis and mumps respectively in cases 4 and 5 is difficult to assess. The failure of the antibody titres to rise under observation is against these infections being responsible for the current illnesses. Glandular fever has often been associated with 'false positive' results in various serological tests (see Carter, 1966), and so caution must be exercised in interpreting the presence of antibodies found unexpectedly in cases considered on other grounds to be glandular fever. In case 7, it is possible that there were two events, an E.C.H.O. virus type 9 infection accounting for the earlier, rather vague, part of the illness, followed by glandular fever. Facial palsy seems to have been recorded much more often in glandular fever than in E.C.H.O. virus type 9 infection (Penman, 1966). Thus it seems doubtful if the infections discussed gave rise to more than a part of the illnesses in cases 4, 5, and 7 .

Viruses in other cases may have died before the specimens reached the laboratory or may have been unable to infect the tissue cultures used. Nevertheless, adeno-, E.C.H.O., Coxsackie, and polio viruses had all been isolated by the same methods in other cases. Antibodies against antigens other than those employed in the complement fixation tests, however, would have escaped detection. Seronegative glandular fever has often been noted to show some degree of infectivity or even to occur in epidemics (Shubert et al., 1954; Hobson et al., 1958). The present seven cases were sporadic, but investigations of epidemic cases of seronegative glandular fever may well yield results different from those recorded here.

Although six of the present seven patients belonged to blood group $\mathrm{O}$, in France such patients are usually found to belong to group A (Eyquem, 1962; Grenet, Chavelet, and de Paillerets, 1962). The latter group of authors even regarded a patient's belonging to group A as compensating, in diagnosis, for a negative heterophile agglutination reaction. Of Salo's 10 seronegative patients, three belonged to group $\mathbf{O}$ and five to group A (Salo, 1966). Evans (1960), however, found that 10 of his 19 seronegative patients belonged to group $O$.

Several authors have previously noted a tendency for childhood cases of glandular fever to be seronegative (Belfrage, 1962; Vahlquist, Ekelund, and Tveterås, 1958; Bernstein, 1940; Hobson et al., 1958; Salo, 1966). Belfrage and Salo also noted seronegative patients above the usual glandular fever age range. The age incidence observed in the present small series was very different from that characteristic of the sero- 
positive disease, but in no case could the entire illness be easily ascribed to any cause other than glandular fever. Some of the seven showed sheep cell agglutinins that were very weak, but otherwise typical of glandular fever; others showed no trace of such agglutinins. It seems likely that the former cases represented an illness of the same nature as the seropositive disease, but in which the serological response had been greatly modified in some way by the patients' ages. The latter cases may have been of the same nature but with an even greater suppression of serological response, though toxoplasmosis, mumps, and E.C.H.O. virus type 9 may have played a part in three of the cases, and the possibility of other infections as, for instance, with cytomegalovirus, has not been excluded.

I am grateful to the general practitioners who referred the cases to me, and to those who kindly carried out various special investigations, especially Drs. D. G. Fleck and L. A. Hatch, and Dr. M. T. Parker, Director of the Streptococcus Reference Laboratory, Colindale. The work described here formed a part of a thesis accepted for the degree of M.D. at Cambridge University, and a part of an essay which was awarded a prize in the annual competition held by the Wessex Regional Hospital Board.

\section{REFERENCES}

Belfrage, S. (1962). Acta med. scand., 171, 531.

Bernstein, A. (1940). Medicine (Baltimore), 19, 85.

Beverley, J. K. A., and Beattie, C. P. (1958). Lancet, 2, 379.

Carter, R. L. (1966). Brit. J. Haemat., 12, 268.

Conway, H. (1949). Brit. med. J., $2,787$.

Davidsohn, I., and Lee, C. L. (1962). Med. Clin. N. Amer., 46, 225.

- , (1964). Amer. J. clin. Path., 41, 115.

Dunsford, I., and Bowley, C. C. (1955). Techniques in Blood Grouping, p. 190. Oliver and Boyd, Edinburgh and London.

Evans, A. S. (1960). Amer. J. Hyg., 71, 342.

Eyquem, A. (1962). Rev. Prat. (Paris), 12, 2703.

-, Fine, J., Mailloux, M., and Podliachouk, L. (1955). Sang, 26. 664.

Fleck, D. G., and Payne, R. A. (1963). Mth. Bull. Minist. Hlth Lab. Serv., $22,97$.

Fraser, P. K., and Hatch, L. A. (1959). Brit. med. J., 1, 470.

Girard, K. F., and Murray, E. G. D. (1951). Amer. J. med. Sci., 221, 343.

Grenet, P., Chavelet, F., and de Paillerets, F. (1962). Rev. Prat. (Paris), 12, 2675.

Hobson, F. G., Lawson, B., and Wigfield, M. (1958). Brit. med. J., 1 845.

Hoff, G., and Bauer, S. (1965). J. Amer. med. Ass., 194, 351.
Klemola, E., and Kääriäinen, L. (1965). Brit. med. J., 2, 1099.

Lawrence, A. (1960). Ibid., 2, 1736.

Lee, C. L., Takahashi, T., and Davidsohn, I. (1963). J. Immunol., 91 783.

Leibowitz, S. (1953). Infectious Mononucleosis. New York; Grune and Stratton.

Levine, P., and Gilmore, E. L. (1945). Science, 101, 411.

Lichtenstein, M. R., and Cannemeyer, W. (1953). J. Amer. med. Ass. 152, 606.

Lowe, J., and Smith, M. (1949). Int. J. Leprosy, 17, 181.

Mason, J. K. (1951). J. Hyg. (Lond.), 49, 471.

Misao, T., Kobayashi, Y., and Shirakawa, M. (1957). Sang, 28, 785

Niederman, J. C. (1956). Yale J. Biol. Med., 28, 629.

Penman, H. G. (1966). Glandular Fever and Glandular Fever-Lik $\vec{\varnothing}$ Illness. M.D. Thesis, Cambridge.

Ross, B. A. (1964). Thorax, 19, 159.

Salo, O. P. (1966). Ann. Med. exp. Fenn., 44, suppl. 1.

Shubert, S., Collee, J. G., and Smith, B. J. (1954). Brit. med. J., 页

Siim, J. C. (1960). Human Toxoplasmosis; Proceedings of the Conferiv ence on Clinical Aspects and Diagnostic Problems of Toxoplasmosis in Paediatrics at the VIII International Congress of Paediatrics' Copenhagen, 1956. Edited by J. Chr. Siim, p. 53cr Munksgaard, Copenhagen

Smith, D. R. (1964). Brit. med. J., 1, 945.
Vahlquist, B., Ekelund, H., and Tveterås, E. (1958). Acta paediat. (Uppsala), 47, 120.

\section{ADDENDUM}

Since this paper was written, stored sera which werę용 still available from five of the cases were tested foro complement-fixing antibody to cytomegalovirus: The results are as follows:-

\begin{tabular}{ccc} 
Case No. & C.F.T. Titres & Days after Onset of Illness \\
\hline 1 & $<8$ & 70 \\
2 & $<8$ & 21 \\
4 & $<8$ & 88 \\
5 & $<8$ & 28 \\
6 & $<8$ & 18 \\
68 & 31 \\
& $<8$ & 28
\end{tabular}

In case 5 there is thus definite evidence of recen infection with cytomegalovirus, and in case 6 this infection is not excluded as a cause of the illness. It seems very unlikely that cytomegalovirus was the cause of the illness in cases 1,2 , and 4 .

I am grateful to Dr. H. Stern, of St. George's Hospitalp London, for kindly carrying out these tests. 